\title{
Physiological and Molecular Defense Level in Potato Cultivars against Potato Virus X
}

\author{
Noha K. El-Dougdoug ${ }^{1}$ and Naglaa M.Balabel ${ }^{2,3}$ \\ 1-Microbiology and Botany Dept. Faculty of Science, Benha University, Egypt. \\ 2- Plant Pathology Research Institute, Agricultural Research Center (ARC), Giza, Egypt. \\ 3- Potato Brown Rot Project (PBRP), Ministry of Agriculture and Land Reclamation, \\ Dokki, Egypt.
}

\begin{abstract}
Potato virus X (PVX) causes severe losses in worldwide crops of family Solanaceae. Dramatic biochemical changes in virus infected plants due to decrease in qualitative and quantitative of yield crops. The current study demonstrate the changes of biochemical responses as a defense level and resistance genes in infected plants against virus infection. PVX isolate was confirmed by double antibody sandwich enzyme-linked immunosorbent assay (DAS-ELISA). This study was performed on five cultivars of imported seeds potato PVX tested, Diamond, Hermes, Lady Rosetta, Nicola, and Spunta . All potato cultivars were infected with PVX isolate. The five potato cultivars showed variations symptoms development, disease severity and virus concentration .The potato cultivars against PVX infection exhibited significantly increase in physiological alterations (electrolyte leakage, cell membrane stability and transpiration rate) and biochemical responses defense (total proline, stabilizing phenols, scavenging enzymes, catalase, peroxidase, polyphenol oxidase, superoxide dismutase, activities) and $\mathrm{RX} 1, \mathrm{RX} 2, \mathrm{RX} 3$ genes resistance compared to healthy ones. According to viral assessment, physiological parameters, biochemical responses and RX resistance genes, the five potato cultivars were divided to resistant cv., Diamond, tolerant cv., Hermes, Lady Rosetta, Nicola and susceptible cv., Spunta
\end{abstract}

Keywords: Potato cultivars, PVX, scavenging enzymes activities and physiological marker response.

\section{Introduction}

Potato virus X (PVX), family Alphaflexiviridae, genus Potexvirus) is one of over 30 viruses that infect potato crops (Nyalugwe et al., 2012 and Fayziev \& Vakhabov, 2019) . Potato (Solanum tuberosum) is most important food crop worldwide as a fourth one. Egypt is also standing among the world top potato exporter (Crissman, et al., 1991 ; Hegazy, 2009; El-Dougdoug et al., 2014 and Faostat, 2018) . Resistance genes against Potato virus $X(\mathrm{PVX})$ are known, but genes confer resistance to the migration of PVX from leaves to tubers of potato plants are remains unknown. Ohbayashi et al., (2019) was detected SCAR marker in eleven potato cultivars and breeding potato lines exhibited resistance to PVX migration from leaves . The Rx gene was inherited as immune resistance by a single dominant gene. Within the SCAR marker, Rx had a higher sequence similarity with $\mathrm{Rx} 1$ than with $\mathrm{Rx} 2$ and suggested that Rx and Rx1 are the same gene derived from the $S$. tuberosum subsp. andigena. PVX isolates divided into several pathotypes according to are able to overcome the RX and / or $\mathrm{RX}$ resistance genes and the $\mathrm{Nb}$ and / or $\mathrm{Nx}$ resistance genes are already present in the $\mathbf{E U}$ (Fayziev et al.,2020). These Rx breaking isolates could potentially have an additional impact over the current situation in the EU and therefore meet all the criteria to qualify as a potential Union quarantine pest. All other non-EU isolates, should they be introduced, are not expected to have additional impact and therefore do not meet this criterion to qualify as a potential Union quarantine pest (Dehnen-Schmutz et al., 2020). Phytopathogen viruses affect negatively the physiological properties of plants and reduce the efficiency productivity of photosynthesis in plant leaves, as a result, the productivity of plants decreases. Dramatic biochemical changes in virus infected plants result in a decrease in both quality and quantity of infected crops. Various reports suggest that virus multiplicity inside the plant cell modulate different biochemical constituents of plants and deactivate the physiological processes like photosynthesis, transpiration and respiration of the infected plants which affect the growth and yield (Tajul, et al., 2011). It well known that stress on the plant causes generation of excessive reactive oxygen species (ROS), which leads to cell toxicity, membrane dysfunction and cell death (Chookhampaeng, 2011)

Plants have developed an enzymatic and no enzymatic mechanism to scavenge ROS (Sofy et al., 2017). Among the active oxygen species superoxide is converted by SOD enzyme to $\mathrm{H}_{2} \mathrm{O}_{2}$, which is further scavenged by CAT and APX. Overexpression of the PX gene in plants has shown improvement in protection against oxidative stress (Sevengor, et al., 2011).The present study utilized five infected potato cultivars plants that have different infection response to PVX as a tool to estimate the sensitive immune response of each potato cultivars to virus infection. Some physiological and phytochemical parameters are 
crucial for selecting at least one cultivar that could resist PVX.

\section{Material and Methods}

Source of PVX isolate: PVX isolate was kindly obtained from Virology Lab, Dept. of Agric. Microbiology, Fac. of Agric., Ain Shams University, Cairo, Egypt. PVX isolate was confirmed based on DAS-ELISA (Clark \& Adams, 1977).

Plant Materials: Class E seed tubers used in this study were kindly provided by the Potato Brown Rot Project, Ministry of Agriculture and Land Reclamation, Dokki, Giza. The cultivars Diamond, Hermes, Lady Rosetta, Nicola, and Spunta were PVX tested by DAS-ELISA using specific polyclonal antibodies kits (LOEWE Biochemical

GmbH Germany) .

Experiment design: Twenty tubers from each potato cultivar PVX tested were planted in plastic bags containing sterilized clay soil (diameter $30 \mathrm{~cm}^{2}$, one tuber per bag). Ten potato plants after 2 weeks from planted were mechanically inoculated with PVX isolate and another ten potato plants left without inoculation as a control and maintained under greenhouse at $16 \mathrm{~h}$ day light and $26^{\circ} \mathrm{C}$ condition. The practical agriculture recommended were applied. The development symptoms were recorded and confirmed by DAS-ELISA.

Virus infectivity and disease severity: The virus infectivity and degree of disease severity for each potato cultivar were determined according to (Loebenstein \& Gaba, 2012).

Determination of electrolyte leakage : The total inorganic ions leaked out from the leaves were measured by the method described by (Sullivan and Ross, 1979). Twenty leaf discs were taken in a boiling tube containing $10 \mathrm{~cm}^{3}$ of deionized water. The tubes were heated at $45^{\circ} \mathrm{C}\left(\mathrm{EC}_{\mathrm{a}}\right)$ and $55^{\circ} \mathrm{C}\left(\mathrm{EC}_{\mathrm{b}}\right)$ for $30 \mathrm{~min}$ each in water bath and the respective $\mathrm{EC}$ were measured by conductivity meter. Later the contents were boiled at $100^{\circ} \mathrm{C}$ for $10 \mathrm{~min}$ and the $\mathrm{EC}$ was again recorded as $\left(\mathrm{EC}_{\mathrm{c}}\right)$. The electrolyte leakage was calculated by using the formula:

Electrolyte leakage $(\%)=\left(\mathrm{EC}_{\mathbf{b}}-\mathrm{EC}_{\mathrm{a}} / \mathrm{EC}_{\mathbf{c}}\right) \times 100$

Determination of membrane stability Index (MSI): MSI estimated by taking $200 \mathrm{mg}$ of leaves in $10 \mathrm{~cm}^{3}$ of double distilled water in two sets. One set heated at $40^{\circ} \mathrm{C}$ for $30 \mathrm{~min}$. in a water bath and the electrical conductivity $(\mathrm{C} 1)$ was measured. Whereas, the second set was boiled at $100^{\circ} \mathrm{C}$ in water bath for $10 \mathrm{~min}$. and its conductivity was also measured (C2) - Both conductivities $\mathrm{C} 1$ and $\mathrm{C} 2$ were measured using conductivity meter. MSI calculated using the formula described by (Sairam, 1994)
$\mathrm{MSI}=[1-(\mathrm{C} 1 / \mathrm{C} 2) \times 100]$

Determination of transpiration rate: The method used for measuring the speed rate of transpiration described by (El Rahman and Batanouny, 1965). The cut surfaces of the detached parts were smeared with petroleum jelly and rapidly weighted. They were then exposed in the open air under natural conditions for $2 \mathrm{~min}$. and weighted again. The decrease in weight corresponds to the water lost by transpiration during the period of exposure. The results calculated by new vegetative weight of plants.

Determination of phenolic compounds: Extraction of phenolic compounds was carried out according to the method of Dai \& Mumper, (2010) and the colorimetric method of Folin-Denis as described by Reda et al., (2014) was used for the chemical determination of phenolic compounds.

Determination of free proline: Determination of free proline was carried out according to the method of Bates et al., (1973). The proline concentration was determined from a standard curve of free proline and toluene for blank.

Determination of enzyme activities:

Extraction of proteins : Two $g$ of the plant materials were homogenized with $10 \mathrm{ml}$ of phosphate buffer pH $6.8(0.1 \mathrm{M})$, then centrifuged at $20000 \mathrm{rpm}$ for 20 min under cooling $\left(2^{\circ} \mathrm{C}\right)$. The clear supernatant (containing the enzymes) was taken as the enzymes source (MuKherjee and Choudhuri, 1983 ).

Superoxide dismutase (SOD) activity was determined by measuring the inhibition of the autooxidation of pyrogallol using the method described by (Marklund \& Marklund, 1974).

Catalase (CAT) activity assayed according to the method of (Anshu Gupta, 2015) - Peroxidase (POX) activity assayed according to the method of (Wahlefeld \& Bergmeyer, 1974) . Polyphenol oxidase (PPO) activity determined according to the method adopted by (Matta \& Dimond, 1963).

\section{Detection of gene resistance:}

DNA extraction from potato leaves was performed by hexadecyl trimethyl ammonium bromide (CTAB) according to Wulff et al. (2002).

Amplification of Rx genes : Three primers of $\mathrm{Rx}$ gene Rx1, Rx2 and Rx3 (manufactured by Bioron) with the product sizes 215, 221 and $241 \mathrm{bp}$, respectively were designed by Mahfouze, 2008 (Table 1). 
Table 1. Characteristics of designed primers specific to Ry and Rx genes resistant to PVX.

\begin{tabular}{lllll}
\hline $\begin{array}{l}\text { Primers for } \\
\text { Rx genes }\end{array}$ & $\begin{array}{l}\text { Primer sequences of forward }(\mathrm{d}) \\
\text { and reverse }(\mathrm{r})\left(5^{\prime} . . .3^{\prime}\right)\end{array}$ & Site on genome & $\begin{array}{l}\text { Product } \\
(\mathrm{bp})\end{array}$ & size \\
\hline Rx2 & F CAAGTTGGGGAATGGCTAAA & $7859-8079$ & 221 \\
& R TTGAGGATTCGTCAAGGTAG & & \\
Rx 1 & F TTTTGCCCTTTCGGTAGTTG & $1039-1249$ & 215 \\
Rx 3 & R ACAGACCCGTTTCGACATTC & $15103-15343$ & 241 \\
& $\begin{array}{l}\text { F GCATAGGTGGCAAGGATGAT } \\
\text { R CAACTGTGTTCCCGTGAATG }\end{array}$ & & \\
\hline
\end{tabular}

The reaction mixture consisted of $2.5 \mu 1$ of $10 \mathrm{x}$ PCR buffer, $1.5 \mu \mathrm{l}$, of $50 \mathrm{mM} \mathrm{MgCl} 22,2.5 \mu \mathrm{l}$ of $\mathrm{mM}$ dNTP, $0.5 \mu \mathrm{l}$ of each $10 \mathrm{mM}$ primer forward and $10 \mathrm{mM}$ primer reverse , $2 \mu \mathrm{l}$ of $50 \mathrm{ng}$ DNA , $1 \mu \mathrm{l} 5$ units Taq DNA polymerase, and $14.5 \mu$ M Millipore $\mathrm{H}_{2} \mathrm{O}$. Reactions were carried out in a DNA thermocycler (Biometra, biomedizinische Analytik $\mathrm{GmbH})$. The PCR was performed with the cycling program of denaturation (one cycle) $94^{\circ} \mathrm{C}$ for 4 min., 35 cycles for $\left\{1 \mathrm{~min}\right.$.at $94^{\circ} \mathrm{C}, 1 \mathrm{~min}$. at $55^{\circ} \mathrm{C}$ and 1 min. at $72{ }^{\circ} \mathrm{C}$ \}followed by a final extension period of $5 \mathrm{~min}$. at $72^{\circ} \mathrm{C}$. PCR amplified products were analyzed using $1.2 \%$ agarose gel electrophoresis in (1X) TBE buffer staining with ethidium bromide. The amplified DNA bands were visualized under UV light and the sizes of the fragments were estimated based on a DNA ladder of 100 to $1000 \mathrm{bp}$ (manufactured by Bioron).

\section{Statistical analysis:}

All plant chemical analysis data were statistically analyzed using Two-way ANOVA and Holm-Sidak test SigmaPlot 12.0 at 0.05 level of probability (Milliken \& Johnson, 2009). The values recorded in the values of the biochemical analysis are means of three replicates.

\begin{abstract}
Results
The interaction of potato cultivars with PVX isolate

The five potato cultivars PVX tested were differed in sensitivity to PVX in terms of symptoms, disease severity and virus concentration based on obvious results in Table (2). The five potato cultivars were showed different type of systemic symptoms for example, Diamond cv. showed mild mosaic and vein necrosis, Hermes and Nicola cv showed vein clearing, severe mosaic and leaf deformation, Lady Rosetta cv revealed mild mosaic and vein necrosis. While Spunta cv showed vein clearing, severe mosaic, crinkling and vein necrosis. The percentage of disease severity was $22.3,27.5,45.6,36.3, \%$ and $56.5 \%$ for five potato cultivars respectively. The virus concentration was determined by DAS-ELISA as, $0.121,0.139,0.163,0.152$, and 0.275 Optical density at $405 \mathrm{~nm}$ for five potato cultivars respectively whereas the negative control was 0.042 O.D. According to the reaction of potato cultivars with PVX isolate, five potato cultivars can be divided into: Diamond is resistant (R), Hermes, Nikola, and Lady Rosetta are tolerant ( $\mathrm{T}$ ) while Spunta is susceptible (S).
\end{abstract}

Table 2. Susceptibility of five potato cultivars to infection with PVX

\begin{tabular}{|c|c|c|c|c|}
\hline Potato cultivar & and Susceptibility & $\begin{array}{c}\text { Symptom } \\
\text { Development }\end{array}$ & $\begin{array}{c}\text { Disease } \\
\text { Severity }(\%)\end{array}$ & $\begin{array}{l}\text { ELISA } \\
\text { reading }\end{array}$ \\
\hline Diamond & Resistant (R) & $\mathrm{MM} ; \mathrm{VN}$ & 22.3 & 0.121 \\
\hline Hermes & Tolerant $(\mathrm{T})$ & VC; SM; LD. & 27.5 & 0.139 \\
\hline Lady Rosetta & Tolerant (T) & $\mathrm{MM} ; \mathrm{N}$ & 36.3 & 0.152 \\
\hline Nicola & Tolerant (T) & VC; SM; LD. & 45.6 & 0.163 \\
\hline Spunta & Susceptible(S) & VC; SM; C; VN. & 56.5 & 0.275 \\
\hline
\end{tabular}

$\begin{array}{lcc}\mathrm{VC}=\text { vein clearing, } & \mathrm{MM}=\text { mild mosaic }, & \mathrm{SM}=\text { severe mosaic }, \quad \mathrm{M}=\text { mosaic, } \\ \mathrm{LD}=\text { leaf deformation } & \mathrm{C}=\text { crinkling }, & \mathrm{VN}=\text { vein necrosis }\end{array}$

Optical density at $405 \mathrm{~nm}, \quad$ Negative control $=0.042, \quad$ Positive control $=0.27$

\section{Physiological responses}

Electrolyte leakage (EL) and membrane stability index (MSI): Stability enables for assessing the injury of the cell membrane. Data recorded in Table (3) revealed that potato cultivars showed significant differences in (EL) \& (MSI). The potato cultivars under the virus stress influence showed different responses in the rate of EL \& MSI stability comparing with healthy ones. The results in Table (3) showed significantly increased rates of (EL) in the four infected cultivars except Hermes (T) that had non-significant decrease in the ratio of EL, while Diamond (R) elevated up to $50 \%$ significant increasing .On the other hand, infected plants of Diamond (R) and Hermes (T) showed significant increasing while, Nicola (T), Lady Rosetta (T) and Spunta (S) showed significant decreasing values of (MSI). 
Table 3. Effect of PVX on electrical leakage $\%$ and membrane stability $\%$ of potato cultivars by two way analysis of variance (ANOVA).

\begin{tabular}{|c|c|c|c|c|}
\hline \multirow{2}{*}{$\begin{array}{l}\text { Potato } \\
\text { cultivars }\end{array}$} & \multicolumn{2}{|c|}{ Electrolyte Leakage \% } & \multicolumn{2}{|c|}{ Membrane stability index \% } \\
\hline & Healthy & Infected & Healthy & Infected \\
\hline Diamond (R) & $13.90 \pm 0.34$ & $29.80 \pm 0.60 \mathrm{~S}$ & $70.80 \pm 0.50$ & $72.50 \pm 0.50 \mathrm{~S}$ \\
\hline Nicola $(\mathrm{T})$ & $18.80 \pm 0.25$ & $20.50 \pm 0.30 \mathrm{~S}$ & $77.00 \pm 0.40$ & $73.60 \pm 0.30 \mathrm{~S}$ \\
\hline Hermes $(\mathrm{T})$ & $36.50 \pm 0.50$ & $35.40 \pm 0.40 \mathrm{NS}$ & $66.03 \pm 0.40$ & $68.60 \pm 0.35 \mathrm{~S}$ \\
\hline Lady Rosetta (T) & $9.80 \pm 0.50$ & $21.10 \pm 0.70 \mathrm{~S}$ & $84.10 \pm 0.41$ & $75.60 \pm 0.40 \mathrm{~S}$ \\
\hline Spunta $(\mathrm{S})$ & $30.80 \pm 0.45$ & $33.00 \pm 0.50 \mathrm{~S}$ & $66.80 \pm 0.40$ & $59.80 \pm 0.85 \mathrm{~S}$ \\
\hline
\end{tabular}

Each value is mean of 4 replicates \pm standard error of means

NS $=$ Non significant

$\mathrm{S}=$ Significant at $\mathrm{P}<0.05$

Transpiration rate : PVX infected were increased transpiration rate $\left(\mathrm{gm} / 100 \mathrm{~cm}^{2} /\right.$ hour $)$ at 24 hours during (20-21/1/2019) of five potato cultivars during night day (Table, 4). The infected Diamond (R) showed the highest-level with the mean 18.63 / 100 cm2/ hour compared healthy one 11.14 / $100 \mathbf{c m} 2 /$ 24 hour, Nicola (T) indicated the highest-level 17.14 compared healthy one 10.28/ $100 \mathrm{~cm} 2 / 24$ hour . Followed by Hermes (T) with the mean 14.7/
$100 \mathrm{~cm} 2 / 24$ hour compared healthy one 8.08/ 100 cm2/ 24 hour and Spunta $(\mathrm{S})$ indicated the highestlevel 14.26 compared healthy one 11.14 mean in transpiration rate $\mathrm{g} / 100 \mathrm{~cm}^{2} /$ hour. While, infected Lady Rosetta $(\mathrm{T})$ plants indicated the lowest level 11.66 compared healthy one 10.28 mean in transpiration rate $\mathrm{g} / 100 \mathrm{~cm}^{2} /$ hour during the study period.

Table 4. Effect of PVX on relative humidity (\%), and transpiration rate $\left(\mathrm{gm} / 100 \mathrm{~cm}^{2} /\right.$ hour) of potato cultivars.

\begin{tabular}{|c|c|c|c|c|c|c|c|c|c|c|c|c|}
\hline \multirow[t]{3}{*}{ Time } & \multirow[t]{3}{*}{ RH\% } & \multirow[t]{3}{*}{ Tem $^{0} \mathrm{C}$} & \multicolumn{10}{|c|}{ Transpiration rate g/ $100 \mathrm{~cm} 2 /$ hour } \\
\hline & & & \multicolumn{2}{|c|}{$\begin{array}{c}\text { Diamond } \\
(\mathbf{R})\end{array}$} & \multicolumn{2}{|c|}{$\begin{array}{l}\text { Hermes } \\
(\mathrm{T})\end{array}$} & \multicolumn{2}{|c|}{$\begin{array}{c}\text { Lady Rosetta } \\
(\mathrm{T})\end{array}$} & \multicolumn{2}{|c|}{$\begin{array}{c}\text { Nicola } \\
(\mathbf{T})\end{array}$} & \multicolumn{2}{|c|}{$\begin{array}{c}\text { Spunta } \\
\text { (S) }\end{array}$} \\
\hline & & & $\mathbf{H}$ & $\mathbf{I}$ & $\mathbf{H}$ & I & $\mathbf{H}$ & $\mathbf{I}$ & $\mathbf{H}$ & I & $\mathbf{H}$ & I \\
\hline $3 \mathrm{pm}$ & 45 & 16 & $15.8 *$ & 17.4 & 17.7 & 21.5 & 19.8 & 13.3 & 12.5 & 23.3 & 6.8 & 8.6 \\
\hline $6 \mathrm{pm}$ & 54 & 15 & 8.8 & 14.2 & 6.6 & 9.9 & 17.6 & 18.3 & 19.9 & 25.5 & 13.1 & 15.5 \\
\hline $9 \mathrm{pm}$ & 71 & 10 & 5.5 & 9.5 & 2.2 & 5.1 & 7.9 & 8.5 & 8.2 & 17.1 & 12.3 & 14.4 \\
\hline $12 \mathrm{am}$ & 71 & 9 & 9.2 & 10.1 & 2.4 & 5.8 & 1.5 & 3.9 & 2.3 & 7.7 & 9.8 & 5.2 \\
\hline $3 \mathrm{am}$ & 71 & 9 & 17.5 & 38.6 & 2.1 & 9.7 & 13.1 & 19.7 & 10.5 & 14.9 & 12.9 & 28.2 \\
\hline $6 \mathrm{am}$ & 78 & 10 & 12.5 & 15.5 & 12.0 & 13.7 & 9.3 & 9.9 & 13.2 & 13.6 & 7.3 & 14.9 \\
\hline 9 am & 63 & 14 & 6.2 & 27.7 & 10.1 & 32.2 & 10.6 & 15.7 & 17.9 & 28.9 & 19.4 & 20.2 \\
\hline $12 \mathrm{pm}$ & 55 & 18 & 15.3 & 24.5 & 7.1 & 12.6 & 9.1 & 9.5 & 3.9 & 9.8 & 9.9 & 11.6 \\
\hline $3 \mathrm{pm}$ & 55 & 16 & 9.5 & 10.2 & 12.5 & 21.8 & 3.6 & 5.6 & 4.1 & 13.5 & 8.8 & 9.7 \\
\hline Total & 563 & 117 & 100.3 & 167.7 & 72.7 & 132.3 & 92.5 & 104.9 & 92.5 & 154.3 & 100.3 & 128.3 \\
\hline Mean & 62.5 & 13 & 11.14 & 18.63 & 8.08 & 14.7 & 10,28 & 11.66 & 10,28 & 17.14 & 11.14 & 14.26 \\
\hline
\end{tabular}

*Each value is mean of 4 replicates.

\section{Biochemical defense}

Phenols and proline contents: Data in Table (5) revealed a differences in total phenol and proline contents of five potato cultivars. PVX infected Diamond, Lady Rosetta and Spunta potato varieties showed significant increase in total phenol and proline contents. Hermes, potato cv. showed significant decrease in total phenol and nonsignificant increase in proline contents. Nicola potato variety showed non-significant increase in total phenol and proline contents compared to healthy plants ones of the shoots.

Table 5. Effect of PVX on phenols and proline (mg/g. dry weight) of potato varieties shoots by two way analysis of variance (ANOVA).

\begin{tabular}{lcccc}
\hline \multirow{2}{*}{ Potato cultivars } & \multicolumn{2}{c}{ Phenol shoot $(\mathrm{mg} / \mathrm{g} \mathrm{dw})$} & \multicolumn{2}{c}{ Proline shoot $(\mathrm{mg} / \mathrm{g} \mathrm{dw})$} \\
\cline { 2 - 5 } & Healthy & Infected & Healthy & Infected \\
\hline Diamond (R) & $0.078 \pm 0.002$ & $0.085 \pm 0.004 \mathrm{~S}$ & $0.42 \pm 0.004$ & $0.75 \pm 0.003 \mathrm{~S}$ \\
Hermes (T) & $0.018 \pm 0.003$ & $0.015 \pm 0.005 \mathrm{~S}$ & $1.38 \pm 0.01$ & $1.5 \pm 0.005 \mathrm{NS}$ \\
Lady Rosetta (T) & $0.056 \pm 0.003$ & $0.075 \pm 0.009 \mathrm{~S}$ & $0.35 \pm 0.03$ & $0.52 \pm 0.004 \mathrm{~S}$ \\
Nicola (T) & $0.010 \pm 0.001$ & $0.024 \pm 0.003 \mathrm{NS}$ & $0.51 \pm 0.006$ & $0.63 \pm 0.008 \mathrm{NS}$ \\
Spunta (S) & $0.015 \pm 0.001$ & $0.019 \pm 0.004 \mathrm{~S}$ & $1.4 \pm 0.02$ & $0.6 \pm 0.002 \mathrm{~S}$ \\
\hline
\end{tabular}

Each value is mean of 4 replicates \pm standard error of means

NS $=$ Non significant

$\mathrm{S}=$ Significant at $\mathrm{P}<0.050$ 
Scavenging enzyme activities: PVX infected five potato varieties revealed differences in the scavenging (Catalase, Peroxidase, Polyphenol oxidase and Superoxide) enzyme activities. Results in the Table (6) showed that Diamond cv showed a significant increase in the scavenging enzyme activities. Hermes cv showed that non-significant increase in Superoxide Dismutase and significantly increased in Catalase and Polyphenol oxidase. Lady
Rosetta cv showed that significant increase in Catalase, Peroxidase and non-significantly increased in Polyphenol oxidase and Superoxide Dismutase . Nicola cv showed that significantly increased in Peroxidase and non-significantly increased in Catalase, Polyphenol oxidase and Superoxide Dismutase . Spunta cv showed significant increase in all enzymes activities except Superoxide Dismutase compared to healthy plants ones .

Table 6. Effect of PVX on Scavenging enzyme activities (unit/g. Fresh wt. /hour) of Potato cultivars by two way analysis of variance (ANOVA).

\begin{tabular}{llllll}
\hline Cultivars & Treatments & Catalase & Peroxidase & $\begin{array}{l}\text { Polyphenol } \\
\text { oxidase }\end{array}$ & $\begin{array}{l}\text { Superoxide } \\
\text { Dismutase }\end{array}$ \\
\hline Diamond (R) & $\mathrm{H}$ & $6.25 \pm 1.25$ & $2 \pm 0.25$ & $0.37 \pm 0.03$ & $5.5 \pm 0.5$ \\
& $\mathrm{I}$ & $7.75 \pm 1.25 \mathrm{~S}$ & $2.5 \pm 0.25 \mathrm{~S}$ & $0.87 \pm 0.03 \mathrm{~S}$ & $6.7 \pm 0.5 \mathrm{~S}$ \\
Hermes (T) & $\mathrm{H}$ & $8.75 \pm 0.5$ & $1.25 \pm 0.25$ & $0.37 \pm 0.09$ & $5.0 \pm 0.5$ \\
& $\mathrm{I}$ & $16.25 \pm 1.25$ & $0.75 \pm 0.00 \mathrm{~S}$ & $0.57 \pm 0.02 \mathrm{~S}$ & $6 \pm 0.00 \mathrm{NS}$ \\
Lady (T) & $\mathrm{H}$ & $12.5 \pm 1.25$ & $1.5 \pm 0.00$ & $0.63 \pm 0.03$ & $3.5 \pm 0.5$ \\
Rosetta & $\mathrm{I}$ & $16.25 \pm 1.25 \mathrm{~S}$ & $2.25 \pm 0.00 \mathrm{~S}$ & $0.67 \pm 0.07 \mathrm{NS}$ & $3.9 \pm 0.5 \mathrm{NS}$ \\
Nicola (T) & $\mathrm{H}$ & $10 \pm 1.25$ & $1 \pm 0.25$ & $0.4 \pm 0.03$ & $5.5 \pm 0.5$ \\
& $\mathrm{I}$ & $10.5 \pm 1.25 \mathrm{NS}$ & $2.75 \pm 0.25 \mathrm{~S}$ & $0.7 \pm 0.06 \mathrm{NS}$ & $5.9 \pm 0.5 \mathrm{NS}$ \\
Spunta (S) & $\mathrm{H}$ & $3.75 \pm 0.00$ & $1 \pm 0.25$ & $0.67 \pm 0.03$ & $7 \pm 0.5$ \\
& $\mathrm{I}$ & $10 \pm 1.25 \mathrm{~S}$ & $2.5 \pm 0.25 \mathrm{~S}$ & $1 \pm 0.06 \mathrm{~S}$ & $7.5 \pm 0.9 \mathrm{NS}$ \\
\hline
\end{tabular}

Each value is mean of 4 replicates \pm standard error of means

$\mathrm{NS}=$ Non significant

$\mathrm{S}=$ Significant at $\mathrm{P}<0.050$

\section{Rx-resistant genes in potato cultivars:}

Three specific primers of $\mathrm{Rx} 3, \mathrm{Rx} 4$, and $\mathrm{Rx} 5$ genes were used to detect the Rx-resistant genes in the five potato cultivars. PCR analysis revealed that, the amplified fragments for the specific $\mathrm{Rx} 3, \mathrm{Rx} 4$, and Rx5 genes with expected sizes 250 bp (Figure, 1). Potato cv. Diamond have high density of Rx3,
Rx4, and Rx5 genes. Potato cv. Hermes have moderate density of Rx3, Rx4, and Rx5 genes. Lady Rosetta have high density of Rx5 gene. Potato cv. Nicola have moderate density of PCR amplification for Rx3and Rx4 genes. Potato cv. Spunta have moderate density of Rx 4 and Rx5 genes (Table, 7).

Table 7. Detection of Rx-resistant genes in potato cultivars by PCR amplification analysis

\begin{tabular}{|c|c|c|c|}
\hline \multirow[t]{2}{*}{ Potato cultivars } & \multicolumn{3}{|c|}{ Rx-resistant genes } \\
\hline & Rx 1 & $\mathrm{R} \times 2$ & $\mathrm{Rx} 3$ \\
\hline Diamond(R) & +++ & +++ & ++ \\
\hline Hermes(T) & + & ++ & + \\
\hline Lady Rosetta(T) & -- & -- & +++ \\
\hline $\operatorname{Nicola}(\mathrm{T})$ & ++ & ++ & -- \\
\hline Spunta(S) & -- & ++ & +++ \\
\hline
\end{tabular}




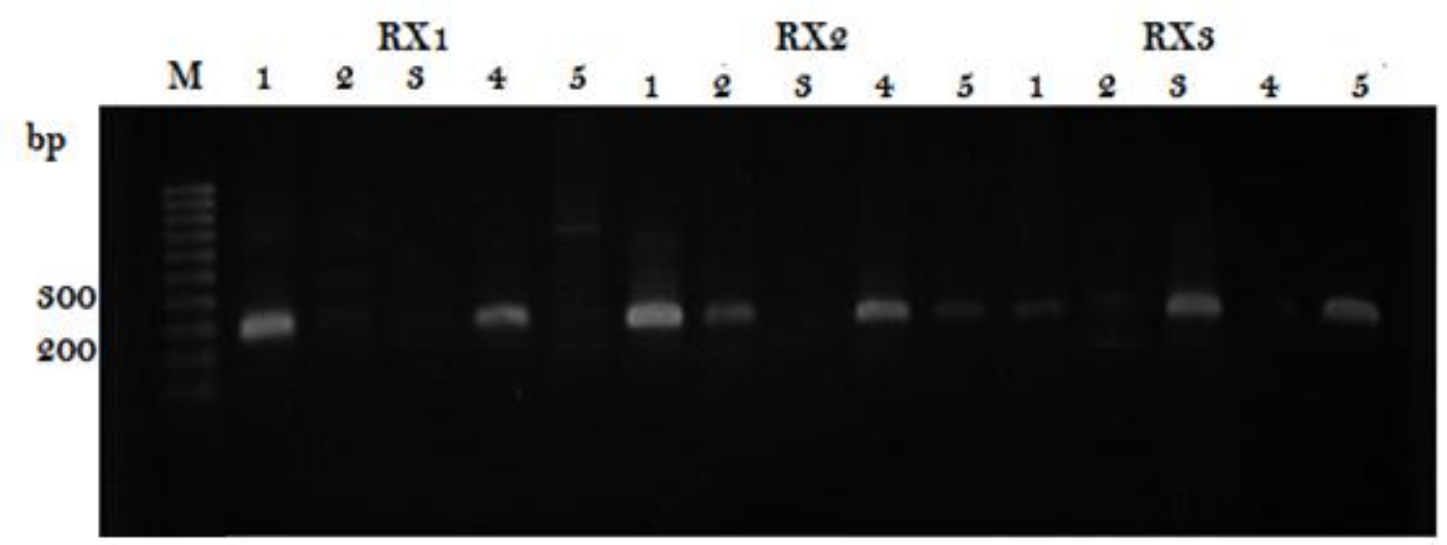

Figure, (1) : Agarose electrophoresis 1.5\% showing PCR amplification of Rx resistance gene using the extended $\mathrm{Rx} 3$, Rx4 and Rx5 primers with expected sizes 250 bp of five potato cultivars; 1-Diamond(R), 2-Hermes(T) 3-LadyRosetta(T), 4-Nicola(T) and 5-Spunta(S).

\section{Discussion}

Potato virus $\mathrm{X}$ is spread in Egypt and all over the world and infects potato cultivar plants (Hegazy, 2009; Mahfouze et al., 2014 and Ohbayashi, 2019). The reaction of potato cultivars with PVX isolate showed differed type of systemic symptoms, disease severity, and virus concentration. Diamond and Hermes showed low disease severity virus concentration . Lady Rosetta and Nicola revealed moderate disease severity and virus concentration . Nicola cv. showed moderate disease severity and virus concentration. While Spunta showed high disease severity and virus concentration . DASELISA was investigated the virus concentration and impacted to the physiological defense level in potato cultivars against PVX . According to the DASELISA results, the rate of the virus concentration decreased inversely in potato cultivars to the response degree of virus infection and disease severity. However, the rates of the virus concentration in potato cultivars have been increased susceptible to the infected virus. Fayziev, et al., 2020) reported the virus concentration was similar between $D$. stramonium leaf samples infected with PVXO-Uz 214 isolate and PVXN-Uz 915 isolate

According to the interaction of potato cultivars with PVX isolate five potato cultivars were Diamond is resistant (R), Hermes, Nikola, and Lady Rosetta were tolerant $(\mathrm{T})$ while, Spunta is susceptible $(\mathrm{S})$. The potato cultivars inoculated with potato viruses showed different susceptibility based on symptoms and ELISA test. (Crissman et al., 1991, Isenegger et al., 2001 and El-Dougdoug et al., 2014).

In general, the responses of plants to pathogen infections are characterized by metabolic changes associated to the development of the symptoms or to defense reactions. Various physiological changes associated to viral infection have been studied such as: decrease in photosynthetic activity, increase in respiration rate, accumulation of nitrogen compounds, increase in polyphenol oxidase activity and alterations in hormonal and secondary metabolisms (Khusanov et al., 2014, Jabeen et al., 2017 and Ananthu and Umamaheswaran., 2019).

Electrolyte leakage (EL) and membrane stability index (MSI) revealed significant differences in potato cultivars under PVX stress influence comparing with healthy ones. It was found significantly increased rates of EL in the four infected cultivars except Hermes(T) that had nonsignificant decrease in the ratio of EL while Diamond (R) elevated up to $50 \%$. Significant increasing .On the other hand, infected plants of Diamond (R) showed Significant increasing while, Nicola (T), Hermes (T), Lady Rosetta and Spunta (S) showed significant decreasing values of (MSI). The potato viruses increased meant of $50 \%$ in (EL) and elevated up to $72 \%$ with MSI comparing with a healthy one according to El Rahman \& Batanouny, 1965 and El-Dougdoug et al., 2014.

Transpiration rate $\left(\mathrm{gm} / 100 \mathrm{~cm}^{2}\right.$ / hour) was increased with PVX infection related to temperature and relative humidity during 24 hours at (2021/1/2019) of five potato cultivars compared healthy ones during night day. The infected Diamond (R) Hermes $(\mathrm{T})$. Nicola $(\mathrm{T})$ and $\operatorname{Spunta}(\mathrm{S})$ indicated the highest-level transpiration rate. While, infected Lady Rosetta (T) plants indicated the lowest level compared healthy one in transpiration rate $\mathrm{g} / 100 \mathrm{~cm}^{2}$ / hour during the study period. In this point, El Rahman \& Batanouny, 1965 and El-Dougdoug et al., 2014 reported that, at $10 \mathrm{PM}-10^{\circ} \mathrm{C}-71 \% \mathrm{RH}$, infected plants of Diamond (R), Nicola (T), and Hermes $(\mathrm{T})$ increased in transpiration rate compared to healthy plants of the same cultivars. Contrary, Lady Rosetta (T) and Spunta(S) cultivars showed decreased in transpiration rate of infected plants compared to healthy ones of the same cultivars (Sullivan \& Ross, 1979).

The five potato cultivars under PVX stress revealed differences in total phenol and proline contents. Diamond and Lady Rosetta cvs. showed significant increase in total phenol and proline 
contents. Contrarily, susceptible cultivar Spunta(S) revealed significant decrease response in the level of proline. Hermes, potato cv. showed significant decrease in total phenol and non-significant increase in proline contents. However, Nicola potato cv. showed non-significant increase of both total phenol and proline contents compared to healthy plants ones of the shoots. The response of Potato cultivars against infected potato viruses exhibited variable physiological alteration defense level parameters. In the green shoot, total proline and Phenols significantly increase. Several types of environmental stress led to proline accumulation such as to response virus infection. The protection of the cell by balancing the osmotic strength of the cytosol. Proline accumulation could be a protective response, not only because of the osmoprotectant role of proline and prevents water-deficit stress under high salinity but also because of the radical scavenger and protein stabilization properties of proline. Also, proline accumulation was reported to serve as a nitrogen storage compound and protect cellular structure (Ben Ahmed et al., 2010).

PVX infected five potato cultivars revealed significant differences increased in the scavenging (Catalase, CAT , Peroxidase, POD, Polyphenol oxidase ,PPO and Superoxide Dismutase, SOD) enzyme activities. Diamond cv showed a significant increase in the scavenging enzyme activities. Hermes cv showed non-significant increase in Superoxide Dismutase and significantly increased in Catalase and Polyphenol oxidase . Lady Rosetta cv showed that significant increase in Catalase, Peroxidase and non-significantly increased in Polyphenol oxidase and superoxide dismutase. Nicola variety showed significantly increased in Peroxidase and nonsignificantly increased in catalase, polyphenol oxidase, Superoxide Dismutase . Spunta cv showed significant increase in all enzymes activities except Superoxide Dismutase compared to healthy plants ones.

Contrarily, susceptible cultivar Spunta (S) indicated a significant increase between healthy and infected plant. While the tolerant cultivars, the enzymes level were differed among CAT, POD, and PPO . This result agreement with Vidya Vardhini and Seeta Ram Rao, (2003) reported that the decrease in POD activity was consistent with the results in plant response under stress and might be an indicator of removal of stressful conditions.

Three specific primers of $\mathrm{Rx} 3, \mathrm{Rx} 4$, and $\mathrm{Rx} 5$ genes were used to detect the Rx-resistant genes in the five potato cultivars. PCR analysis revealed the specific Rx3, Rx4, and Rx5 genes with expected sizes $250 \mathrm{bp}$. Diamond have high density of Rx3, $\mathrm{Rx} 4$, and Rx5 genes. Hermes have moderate density of Rx3, Rx4, and Rx5 genes. Lady Rosetta have high density of Rx5 gene. Nicola have moderate density of PCR amplification for Rx3and Rx4 genes. Spunta have moderate density of $\mathrm{Rx} 4$ and $\mathrm{Rx} 5$ gene.
Molecule role for sugar responsible genes that give a different physiological response to defensive response and cellular expansion (Nyalugwe $\boldsymbol{e t}$ al., 2012; Simaei et al., 2012 and Farahat et al., 2019). The identification of virus resistance genes with similarly conserved structural using the strategy 2conserved sequences corresponding to two coding regions from the disease resistance genes has sparked tremendous interest in developing techniques that could identify other resistance genes that share similar structure but confer resistance to other pathogens. By using a homology based technique, one might be able to decrease both the time and resources required to clone resistance gene. Similar homology-based studies have been reported in different species, such as in potato (Solanum tuberosum) to detect the presence of Ryadg gene for resistance to PVY (Leister et al., 1996 . Baebler,et al.,2020 and Osmani et al.,2021) and in tomato (Lycopersicon esculentum) to identify the resistance gene-like (RGL) sequences (Ohmori et al., 1998). The results obtained in this study revealed that $\mathrm{Rx} 1$, $\mathrm{Rx} 2$ and $\mathrm{Rx} 3$ resistance genes were detected in the PVX resistant plants of Diamond(R) and Hermes(T) . Rx1, Rx2 in Nicola (T) Rx2 and Rx3 in Spunta (S) and $\operatorname{Rx} 3$ gene in Lady Rosetta(T). This was agreed with many reports, for example Cockerham (1970) reported that Rx1 and $\mathrm{Rx} 2$ genes confer ER to potato virus $\mathrm{X}$ (PVX) in $S$. tuberosum ssp. andigena and $S$. acaule, respectively. In the $\mathrm{F} 1$ progeny of crosses between the PVX-susceptible cultivar Huinkel and the cultivar Cara (Rx genotype) there was a 1: 1 segregation of PVX resistance, indicating that Rx in Cara is present in the simplex condition (Bendahmane et al., 1997). The traditional model of a single dominant gene conferring resistance to a specific pathogen species or subspecies has been described in numerous plant/ pathogen systems (Ellis et al., 2000). On the other hand, Ryadg gene was detected in the results in the PVY resistant plants of S. tuberosum subsp. andigena and also in the PVX resistant plants.( Muňoz et al., 1975 and Zheng et al., (2003) . It is interesting to note that Ryadg and $\mathrm{Rx}$ genes in uninfected and resistant plants of wild type species $S$. andigena. These results were confirmed by Nie and Singh (2001). Multiplex-PCR was used for detection on $\mathrm{Rx}$ genes using primers specific for each gene. Products of the expected 158 bp for Rx gene) were observed only in some potato cultivars resistant for PVY and PVX such as $S$. andigena, S. stoloniferum, S. acaule and S. demissum wild type and Spunta cultivar from cultivated potato. While, S. hougasii and Cara contain on Rx gene only thus showed one band with molecular weight $158 \mathrm{bp}$. The technique was 100-fold greater for detection of PVX than that of commercial DAS-ELISA, and also could detect viruses in some samples that DASELISA failed to detect. Mutations of $\mathrm{Glu}^{46}, \mathrm{Asn}^{863}$, $\mathrm{Asn}^{968}$ or Glu ${ }^{1001}$ to Ala in PVX RdRp significantly reduced the viral symptoms. Mutants E1001A and 
E46A could provide effective protection against wild type PVX in both Nicotiana benthamiana and tomato. These results provide theoretical and practical bases for the control of PVX via cross protection (Cong et al., 2019).

\section{References}

Ananthu N, and Umamaheswaran K. (2019). Effect of Viral Infection on Carbohydrate and Chlorophyll Contents in Ginger (Zingiber officinale Rosc.). Int.J.Curr.Microbiol.App.Sci 8(6):862-867.

Anshu Gupta, P. R. (2015). Toxicity Assessment of Municipal Solid Waste Landfill Leachate Collected in Different Seasons from Okhala Landfill Site of Delhi. J. Biomedical Science and Engineering, 8, 357-369.

Baebler,S., Coll,A. and Gruden,K.(2020).Plant Molecular Responses to Potato Virus Y: A Continuum of Outcomes from Sensitivity and Tolerance to Resistance. Viruses.; 12(2): 217. doi: 10.3390/v12020217

Bates, L., Waldren, R., \& Teare, I. (1973). Rapid determination of free proline for water-stress studies. Plant and soil, 39(1), 205-207.

Ben Ahmed, C., Ben Rouina, B., Sensoy, S., Boukhriss, M., \& Ben Abdullah, F. (2010). Exogenous proline effects on photosynthetic performance and antioxidant defense system of the young olive tree. Journal of Agricultural and Food Chemistry, 58(7), 4216-4222.

Bendahmane, A.; K. Kanyuka and D.C. Baulcombe (1999). The $\mathrm{Rx}$ gene from potato controls separate virus resistance and cell death responses. Plant Cell 11, 781-791.

Bendahmane, A.; K.V. Kanyuka and D.C. Baulcombe (1997). High resolution and physical mapping of the $R x$ gene for extreme resistance to potato virus $X$ in tetraploid potato. Theor. Appl. Genet. 95: 153-162.

Chookhampaeng, S. (2011). The effect of salt stress on growth, chlorophyll content proline content and antioxidative enzymes of pepper (Capsicum annuum L.) seedling. European Journal of Scientific Research, 49(1), 103-109.

Clark, M. F., and Adams, A. (1977). Characteristics of the microplate method of enzyme-linked immunosorbent assay for the detection of plant viruses. Journal of General Virology, 34(3), 475483.

Cockerham, G. (1970). Genetical studies on resistance to potato viruses $\mathrm{X}$ and $\mathrm{Y}$. Heredity. 25: 309-348.

Cong, Q. Q. , Wang, Y., Liu, , J. Lan, Y. F. , . Guo, Z. K , . Yang, J. G , Li X,.D.and Tian,Y. P. (2019). Evaluation of Potato virus $\mathrm{X}$ mild mutants for cross protection against severe infection in China, Virology Journal volume 16,: 36

Crissman, C. C., El Bedewy, R., Sabaa, M. F., and Sharaf, M. F. (1991). Agroeconomic evaluation of different types of potato planting material in Egypt: CIP Lima.

Dai, J., and Mumper, R. J. (2010). Plant phenolics: extraction, analysis and their antioxidant and anticancer properties. Molecules, 15(10), 73137352.

Dehnen-Schmutz,K., Gonthier,P and MarieAgnès Jacques(2020). Pest categorisation of potato virus $\mathrm{X}$ (non-EU isolates) EFSA Journal ,18(1):5937 7. DOI: 10.2903/j.efsa.2020.593

El Rahman, A. A., \& Batanouny, K. (1965). Transpiration of desert plants under different environmental conditions. The Journal of Ecology, 267-272.

El-Dougdoug, K. A; Sofy, A.R; Mousa, A.A. and Refaey, E.E. (2014). Monitoring variability responses of cultivated potato varieties infected with Potato virus $Y$ pepper isolate. Egyptian J. Virol., 11 (2): 82-101.

El-Dougdoug, K. A. , Sabah A. D. Ahmed., Hazza M.M. and Kandil. A.A. ( 2014). Monitoring of Microtubers Virus Tested-Derived Potato Tissue Culture by DNA Fingerprint Analysis. International Journal of Virology, 10, 211-223.

Ellis, J.P.; P. Dodds and T. Pryor (2000). Structure, function, and evolution of plant disease resistance genes. Curr. Opin. Plant Biol. 3: 278284.

Faostat, (2018). (http://apps.fao.org).

Farahat A.S., EL-Morsi A.A., Soweha H.E., Sofy A.R. and Refaey E.E. (2019) Metabolic Changes of Cucumber Plants Due to Two CMV Egyptian Isolates. Arab Univ. J. Agric. Sci. Special Issue, 26 (9C): $2019-2028$.

Fayziev V, Vakhabov A (2019) .The study of the biological properties of potato virus $\mathrm{X}$ in common environmental conditions of Uzbekistan// European Sciences review. № 1-2 Volume 2, p. 46-50

Fayziev 1,V., Jovlieva D , Juraeva ,U., Shavkiev, I, Farkhod Eshboev F., and Stat, F. FAO. (2020). Effect of PVX -UZ 915 necrotic isolate of potato virus $\mathrm{X}$ on amount of pigments of Datora stramonium leaves Journal of criteria review 7, issue $9,400-417$

Hegazy, E. S. (2009). Seed potato production in Egypt. Agro-Food Co. Ltd., Egypt.

Isenegger, D. A., Taylor, P. W., Ford, R., Franz, P., McGregor, G. R., \& Hutchinson, J.F. (2001). DNA fingerprinting and genetic relationships of potato cultivars (Solanum tuberosum L.) commercially grown in Australia. Crop and Pasture Science, 52(9), 911- 918.

Jabeen A , Kiran TV, Subrahmanyam D, Lakshmi DL, (2017).Bhagyanarayana $G$ and Krishnaveni D. Variations in Chlorophyll and Carotenoid 
Contents in Tungro Infected Rice Plants // J Res Development, 5:1 DOI: 10.4172/23113278.1000153

Khusanov T.S., Fayziev V.B., Eshboyev F, Davronov K.S, Vakhabov A.Kh. (2014) . Effect of alfalfa mosaic virus on the content of chlorophyll and carotenoids // Bulletin of the Caspian №2. Volume 5, p. 3-5.

Leister, D.; A. Ballvora; F. Salamini and C. Gebhardt (1996). A PCR based

Loebenstein, G., \& Gaba, V. (2012). Viruses of potato. Viruses and Virus Diseases of the Vegetables in the Mediterranean Basin, 84, 209.

Mahfouze, H. (2008). Determination of biochemical and molecular in resistance potato plants to some potato viruses . M.Sc Fac. of agric. Ain shams

Mahfouze, H., El-Sayed, O., El-Dougdoug K. A, O. B., \& Gomaa, M. (2014). Molecular and biochemical markers for resistance to potato virus $\mathrm{Y}$ and potato virus $\mathrm{X}$ in some potato cultivars. Scientia Agriculturae, 1, 49-57.

Marklund, S., \& Marklund, G. (1974). Involvement of the superoxide anion radical in the autoxidation of pyrogallol and a convenient assay for superoxide dismutase. European journal of biochemistry, 47(3), 469-474.

Matta, A., \& Dimond, A. (1963). Symptoms of Fusarium wilt in relation to the quantity of fungus and enzyme activity in tomato stems. Phytopathology, 53(5), 574-582

Milliken, G. A., \& Johnson, D. E. (2009). Analysis of messy data volume 1: designed disease resistance gene-like sequences in near-isogenic lines of tomato. Theor. and Appl. Genet. 96: 331338

Mukherjee, S.P., Choudhuri, M.A. (1983): Implications of water stress-induced changes in the levels of endogenous ascorbic acid and hydrogen peroxide in Vigna seedlings. Physiol. Plant. 58, 166-170.

Muňoz, F.J.; R.L. Plaisted and H.D. Thurston (1975). Resistance to potato virus Y in Solanum tuberosum ssp. andigena. Amer. Potato J. 52: 107-115.

Nie, X. and R.P. Singh (2001). A novel usage of random primers for multiplex RT-PCR detection of virus and viroid in aphids, leaves, and tubers.J. Virol. Methods. 91: 37-49.

Nyalugwe, E. P., Wilson, C. R., Coutts, B. A., and Jones, R. A. C. 2012. Biological properties of Potato virus $\mathrm{X}$ in potato: Effects of mixed infection with Potato virus $\mathrm{S}$ and resistance phenotypes in cultivars from three continents. Plant Dis. 96:43-54.

Ohbayashi , K. (2019). The Rx gene derived USDA 41956 and Rx1 gene derived CPC 1673 confer equal resistance to the migration of Potato virus $\mathrm{X}$ from potato leaves to tubers . Euphytica 215(5) DOI: $\underline{10.1007 / \mathrm{s} 10681-019-2413-6}$
Ohmori, T.; M. Murata and F. Motoyoshi (1998). Characterization of disease resistance gene-like sequences in near-isogenic lines of tomato. Theor. and Appl. Genet. 96: 331-338.

Osmani ,Z., Sabet ,M.S., Nakahara ,K.S., Mokh tassi-Bidgoli , A., Vahabi ,Kh., Ahmad Moieni ,A.and Shams-Bakhsh,M.

(2021).Identification of a defense response gene involved in signaling pathways against PVA and PVY in potato. JournalGM Crops \& Food Biotechnology in Agriculture and the Food Chain. Vol.12, 2021 - Issue 1

Reda, F., Abdelhamid, M. T., \& El-Lethy, S. R. (2014). The Role of $\mathrm{Zn}$ and $\mathrm{B}$ for Improving Vicia faba L. Tolerance to Salinity Stress. Middle East j, 3(4), 707-714.

Sairam, R. (1994). Effects of the homo brassinolide application on plant metabolism and grain yield under irrigated and moisture-stress conditions of two wheat varieties. Plant Growth Regulation, 14(2), 173-181.

Sevengor, S., Yasar, F., Kusvuran, S., \& Ellialtioglu, S. (2011). The effect of salt stress on growth, chlorophyll content, lipid peroxidation and antioxidative enzymes of pumpkin seedling. African Journal of Agricultural Research, 6(21), 4920-4924.

Simaei, M., Khavari-Nejad, R., \& Bernard, F. (2012). Exogenous application of salicylic acid and nitric oxide on the ionic contents and enzymatic activities in $\mathrm{NaCl}$-stressed soybean plants.

Sofy A.R., El-Dougdoug K.A., Mousa A.A. and Refaey E.E. (2017). Impact of Two TYLCV Egyptian Isolates on Metabolic and Antioxidant Activities in Some Tomato Cultivars. Int. J. Adv. Res. Biol. Sci. 4 (2): 110-133.

Sullivan, C. Y., \& Ross, W. (1979). Selecting for drought and heat resistance in grain sorghum. Stress physiology in crop plants, 263-281.

Tajul, M., Naher, K., Hossain, T., Siddiqui, Y., \& Sariah, M. (2011). Tomato yellow leaf curl virus (TYLCV) alters the phytochemical constituents in tomato fruits. Australian Journal univ.179pp.

Vidya Vardhini, B., and Seeta Ram Rao, S. (2003). Amelioration of osmotic stress by infection with potato virus Y. Mol. Plant Microbe Interact. 15: 717-727.

Wahlefeld, A., \& Bergmeyer, H. (1974). Methods of enzymatic analysis. New York, NY, USA:Academic, 1831.

Wulff, E.G.; S. Torres and E.G. Vigil (2002). Protocol for DNA Extraction from potato tubers. Plant Mol. Biol. Reporter, 20: 187a-187e.

Zheng, C.; R. Chang; L. Qiu; P. Chen; X. Wu and S.Chen (2003).Identification and characterization of a RAPD/SCAR marker linked to a resistance gene for soybean mosaic virus in soybean. Euphytica. 132: 199- 210. 


\title{
X الصتوى الدفاع الفسيولوجي والجزيئي في أصناف البطاطس ضد فيروس البطاطس
}

\author{
نهى خالد الاجدج و نجلاء محمد بلابل

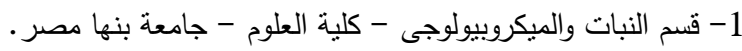 \\ 2- معهذ امراض النبات - مركز البحوث الزراعية - الجيزة - مصر النيات

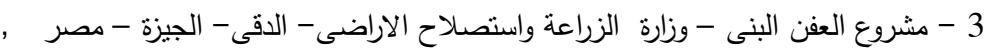

يسبب فيروس البطاطس (PVX) خسائر فادحة في المحاصيل في جميع أنحاء العالم من عائلة الباذنجية Solanaceae . حيث

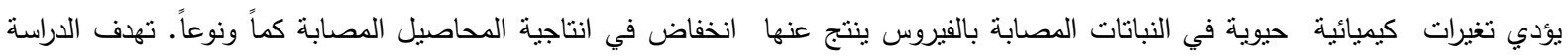

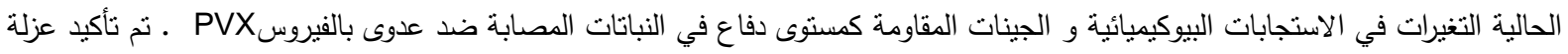
بطريقة الاليزا المباشرة باستخدام اجسام مضادة المرتبطة بالإنزيم PVX

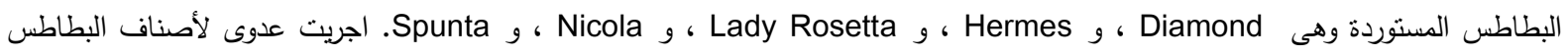

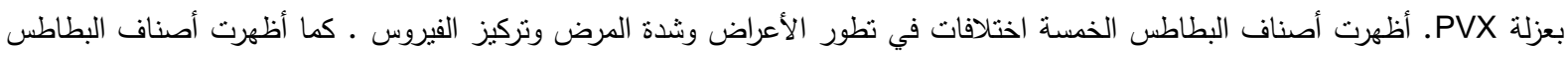

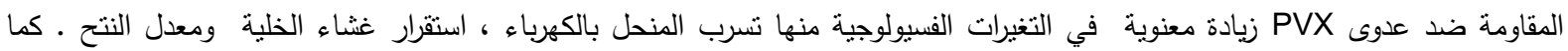

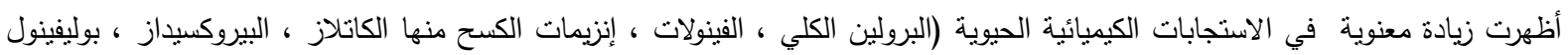

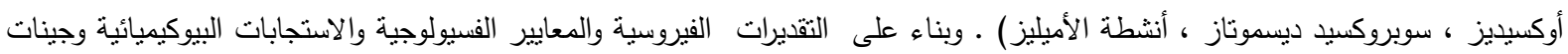
مقاومة RX ، تم تقسيم أصناف البطاطس الخمسة إلى الصنف المقاوم ، الماسي ، الصنف المتسامح ، هيرميس ، ليدي روزيتا ، نيكولا والسيرة الحساسة ، سبونتا. ومقاومة جينات RX مقارنة بالجينات السليمة.

الكلمات المفتاحية: أصناف البطاطس ، PVX ، أنشطة إنزيمات الكسح وإنزيمات amylolytic واستجابة الواسمات الفسيولوجية. 